DOI: $10.1515 /$ pts-2016-0045

APPLIED PHYSICS

\title{
DETERMINATION OF CONTACT POTENTIAL DIFFERENCE BY THE KELVIN PROBE (PART II) \\ 2. MEASUREMENT SYSTEM BY INVOLVING THE COMPOSITE BUCKING VOLTAGE
}

\author{
O. Vilitis ${ }^{1}$, M. Rutkis ${ }^{1}$, J. Busenbergs ${ }^{1}$, D. Merkulovs ${ }^{2}$ \\ ${ }^{1}$ Institute of Solid State Physics, University of Latvia, 8 Kengaraga Street, Riga, \\ LV-1063, LATVIA \\ ${ }^{2}$ Institute of Physical Energetics, 11 Krivu Street, LV-1006, Riga, LATVIA \\ e-mail: oskarsvil@gmail.com
}

\begin{abstract}
The present research is devoted to creation of a new low-cost miniaturised measurement system for determination of potential difference in real time and with high measurement resolution. Furthermore, using the electrode of the reference probe, Kelvin method leads to both an indirect measurement of electronic work function or contact potential of the sample and measurement of a surface potential for insulator type samples. The bucking voltage in this system is composite and comprises a periodically variable component. The necessary steps for development of signal processing and tracking are described in detail.
\end{abstract}

Keywords: Kelvin probe, contact potential difference, surface potential.

\section{INTRODUCTION}

This is a continuation (Part II) of article [1], which presents description of the corona discharge physics. Determination of the surface electric potential difference by the Kelvin probe, i.e., vibrating capacitor technique, is one of the most sensitive measuring procedures in surface physics for contact potential difference (CPD) measurement. This contactless non-destructive method is based on using the traditional Kelvin probe placed plane-parallel to the sample electrode (see Fig. 1a) at a distance $d_{0}$ in stationary state, shaping the simple two-plate capacitor $C$. Based on the previous part of the paper [1], it can be assumed that prior ohmically contacting to the back side of either the electrically conductive or the semiconductor sample electrode to the metallic probe electrode the capacitor electrodes are electrically neutral, no macroscopic electric field arises, and the solids of electrodes share the same local vacuum level.

If the external ohmic circuit is connected to the back sides of sample electrode, and probe electrode charge must flow from electrode substance with smaller 
work function to the electrode substance with larger work function until equilibrium of Fermi levels is achieved. This charge transfers results, in accordance with the law of Volta's serial contacts, as an electric field at the gap between two plates of Kelvin condenser and a drop of a local vacuum level across this gap. Thus, the capacitor at a stationary electrode distance $d_{0}$ capacity $C$ is charged by charge $Q$, and in this case the corresponding potential difference $V_{C P D}$ (Volta potential difference) in a gap between two electrodes is determined by difference of work functions of each electrode substance $V_{C P D}=\Delta \Psi$, see more details [1]. Thereby, CPD must be measured in an open circuit, i.e., using the dielectric such as vacuum or air between the surfaces of inner plates. One might think that $V_{C P D}$ magnitude could be simply calculated considering relationship $Q=C \times V_{C P D}$, and taking into account that the accumulated charge $Q$ of the capacitor and fixed capacitance $C$ can be measured even with the fixed width of the gap between the electrodes. However, it is not so simple to pinpoint the capacitor accumulated charge.

Currently CPD determination is mainly based on Kelvin method where an external potential $V_{B}$ is involved at the Kelvin probe outer circuit, which compensates the potential difference between the capacitor gap electrodes. This unique condition occurs at a potential $V_{B}=-V_{C P D}$ and consequently vanishes the electric field and the potential difference between Kelvin capacitor electrodes $Q \rightarrow 0$ and $V_{C P D} \rightarrow 0$. Thereby, the variable bucking potential $V B$ is adjusted until the Kelvin current vanishes $i \rightarrow 0$. $V B$ is equal and opposite to $V_{C P D}$, the electric field between the capacitor electrodes is compensated, and the zero output signal is recorded, wherein the ac current in the Kelvin probe outer circuit drops to zero.

Periodic modulation of distance between electrodes results in a periodic change of capacitance, whereby, if the potential diference $V_{C P D}$ exists between electrodes, the ac current $i(t)$ flows through capacitor external circuit. Required parameters of this modulation: frequency $f$, modulation depth and amplitude are provided by a driver mechanism. Such CPD compensation procedure is called the nulling of Kelvin probe signal $i(t)$.

At the nulling point, both capacitor electrodes become electrically neutral like in case of disconnected outer circuit. In both cases, the vibrating Kelvin probe cannot create current in an external circuit. Therefore, the basic condition when Kelvin probe does not disturb the studied process is achieved, and the measuring action practically does not influence the contact potential difference measurement.

In the traditional measuring systems, the self-nulling detection of balance point of ac current generated by capacitor is fed to the input of a preamplifier. In this case, the amplifier output voltage is mostly detected applying synchronous detection by using the lock-in amplifier (LIA) with proportional [2], [3] or integral [4], [5] feedback, referenced by probe vibration frequency. As a result, the contact potential of an automatically self-nulling system is formed at the balance point. Such a type of the feedback loop system provides good dynamic properties of $V_{C P D}$ measurements, though it has several serious disadvantages [6]. The value of the voltage drop over Kelvin capacitor becomes negligible around $i(t) \rightarrow 0$ and close to the balance point the parasitic noise signals begin to prevail.The main disadvantage of these systems is a small signal-to-noise ratio at the balance point. Thus, at the low signal level the nulling cannot represent correct balance point, the signal-to-noise ratio becomes 
small and the inversion of phase can emerge. This leads to the sequel of synchronous detection. Consequently, an application of self-compensating LIA systems is limited. To overcome this limitation, the use of the off-null detection was proposed by B. Ritty et al. [7], where the balance point was determined by a linear extrapolation rather than nulling. On the basis of statistical linear correlation-regression analysis of Kelvin current as a function of applied bucking voltage $V_{B}$, the CPD can be derived generally by a good linear correlation coefficient, and errors do not exceed $10 \mathrm{mV}$. A solution to the low signal-to-noise ratio at the balance point is to use measuring methods that permit "off-null" measurements, if the mentioned errors are excluded around $i(t) \rightarrow 0$. After that the calculated data points could be processed by various fitting procedures. In modification of this method developed by I. D. Baikie [8], the peak-to-peak (ptp) output signal $V_{p t p}$ is estimated as a function of bias voltage $V_{B}$ and involves the setting of bucking potential at $\pm 20 \mathrm{mV}$ from the balance point to permit both the high output signal and the accurate determination of in-phase noise components alongside the balance point. The balance point of a voltage drop over the Kelvin capacitor $V_{C P D}$ and bias voltage $V_{B}$ is determined by measuring the $V_{p t p}$ value at different variable bias voltages. The Kelvin signal collected from the vibrating electrode is based on the statistical linear correlation-regression analysis of Kelvin current as the function of applied $V_{B .}$ The extrapolated value $V_{p t p}=0$ is estimated by the data processing program. The complete control and measurement system is PC or microcontroller-steered. Voltage $V_{B}$ is derived from a 12-bit digital-to-analogue converter, which is set to the range of potentials controlled step-wise around the balance point and subsequently digitised by the analogue-to-digital converter for further signal processing by the host PC. The system also incorporates the off-null detection. Application of off-null technique enables measurement of CPD to acquire the best signal-to-noise ratio and is sufficient to produce good quality work function data. The work function resolution of such a system manufactured industrially by KP Technology is of $<3 \mathrm{meV}[9]$.

However, the use of the off-null technique has a few disadvantages. Statistical linear correlation-regression analysis, despite its high complexity in case of area scan at many measurement points, requires the processing of the completed set of measurements [6]. Thus, the online monitoring of Volta potential difference is not possible and the result of measurement can be analysed only after experiment is finished. In addition, the application of the above-mentioned modified off-null technique is generally associated with the need of a PC with pre-installed KP extensive software and use of the external data acquisition digital control unit with a host PC data acquisition system housed in the PC system. This, of course, not only increases the measuring equipment extent and weight, but also raises production costs.

\section{DETERMINATION OF CPD USING THE COMPOSITE BUCKING VOLTAGE SYSTEM}

The design of our potential $V_{C P D}$ measuring system is different in comparison with a measuring system described above; it is based on a simpler technical solution and does not require complicated software. At the same time, we have obtained high resolution in comparison with setups described above [8], i.e., $1-2 \mathrm{mV}$, besides, the 
proposed system provides continuous CPD measuring mode. That way the series of disadvantages mentioned above [1], [6] for such systems are eliminated, which creates preconditions of their wider dissemination and use.

An overview of our CPD measurement system arrangement in simplified form is shown in Fig. 1a. It consists of two basic units: the HEAD STAGE and DATA ACQUISITION SYSTEM (DAS). The HEAD STAGE includes Kelvin condenser C with its electrodes: the sample and the vibrating probe driven by the DRIVER mechanism [10], which is fed by a high-precision sine signal source. This arrangement generates mechanical probe electrode vibration. The PREAMPLIFIER is composed of an ultra-low bias current and low noise input operational amplifier (op-amp) with the dielectrically-isolated FET input and of a precision instrumental output op-amp [10], [11]. The input op-amp makes it possible to implement two functions. Firstly, if input op-amp inverting input is connected to Kelvin probe vibrating electrode, very low current convertion to voltage with a high conversion factor is implemented. The equivalent value of total parasitic input capacitance and corresponding problems of amplifier input are suppressed due to converter low input impedance. Hence, Kelvin probe electrode through the converter input circuit is connected to the so-called virtual ground, i.e., to the sample electrode. Secondly, the CPD compensating or bucking voltage is conveniently involved into the Kelvin capacitor external circuit through converter non-inverting input. Thanks to current-to-voltage converter low impedance, all applied bucking voltage appears in the Kelvin capacitor external circuit. Converter differential output signal is converted to the single-ended output stage using the precision instrumental op-amp.

Our potential $V_{C P D}$ measuring system is based on the fact that at a time $t$ it is continuously generating variable composite bucking voltage $V_{B}(t)$ and is pinpointing the balance point by averaging periodically synchronised data processing.

To pinpoint the potential $V_{C P D}$, in our case the electronically controllable variable voltage $V_{B}(t)$ generator is created that provides the change in the periodical symmetrical triangle wave (saw-tooth) voltage at a time $t$ around the bucking potential balance level $V_{B}$. The polarity and the magnitude of this level determine the relevant parameters of countervailable CPD voltage $V_{C P D}$.

a)

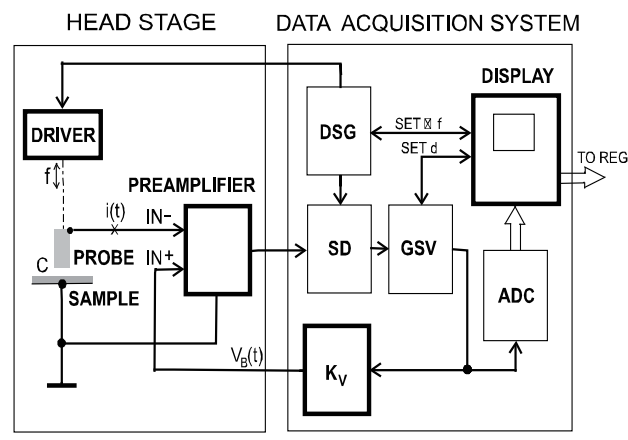

b)

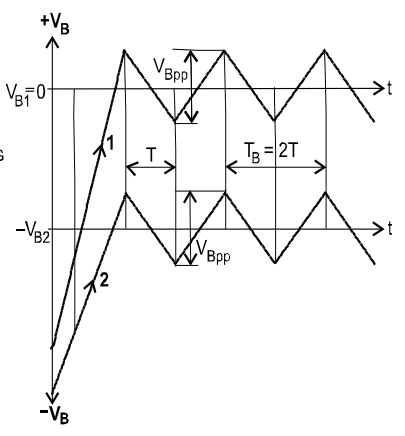

Fig. 1. Schematic diagrams of experimental contact potential difference $V_{C P D}$ measuring system for determination of contact potential diference by Kelvin probe involving the composite bucking voltage: a) Block diagram, where sin generator for driver supply (DSG); synchronous detector (SD); ac voltage amplifier $\left(K_{V}\right)$; stepwise variable bucking voltage generator (GSV); analog-to-digital converter (ADC). b) Variable bucking voltage $V_{B}(t)$ diagrams: (1) $V_{C P D}=0=V_{B I}(t)$, and (2) $V_{C P D}=-V_{B 2}(t)$. 
To illustrate this process, the changes in variable bucking signal $V_{B}(t)$ during the time are displayed in Fig. $1 \mathrm{~b}$ at two balance point values $V_{B I}=0$ and $V_{B 2}$. Electronically controlled generator GSV (Fig. 1a) based on a digital technology plays a specific role for our data acquisition system (DAS), which generates the high precision output voltage that is stepwise linearly growing or decreasing. The bucking voltage $V_{B}(t)$ is formed and applied to the preamplifier non-inverting input IN+ after appropriate amplification by an amplifier $K_{V}$. Generator GSV is controlled by the preamplifier output signal, supplied to the synchrodetector input. From SD output detected signal is supplied directly to the generator control input. At the end of each Kelvin current period $T$ an appropriate polarity control signal is determined, which leads to appearance of stepwise GSV output voltage that is either linearly growing or decreasing. To synchronise the period $T$, the output signal of sine signal generator DSG employed for driver supply is used as the reference signal, which, taking into account the appropriate phase-correction, is supplied to the SD synchronising input. Generator DSG is generating the high precision sinusoidal voltage with frequency $f=118.09 \pm 0.01 \mathrm{~Hz}$ digitally sinthesised from $48 \mathrm{MHz}$ clock signal (the built-in phase locked loop (PLL) can be used to generate a high-frequency system clock), with an external quartz oscillator $16 \mathrm{MHz}$. This voltage supplied to the driver mechanism provides the Kelvin probe vibration. Every moment at the beginning of each interval $T / 256 \mathrm{~s}$ the preamp output signal data are digitised and almost simultaneously prerecorded and analysed in the buffer memory according to the algorithm for SD operation period $T=1 / f=8.468 \mathrm{~ms}$. As a result of data processing, the average values of both the period and the half-period of signal are determined. Thereby the signal switching phase-sensitive half period detection allows creating the control signal of generator GSV approppriate polarities for next period $T$.

At the data acquisition system (DAS), Fig. 1a for visibility reasons displays generators DSG and GSV, synchronous detector SD and analogue-to-digital converter ADC created practically using the microcontroller ATXMEGA16A4U-A where peripheral features - dual channels DAC and ADC - are involved. In accordance with a specially drawn algorithm, one of microcontroller digital-to-analogue converter DAC channels is used to synthesise the sinusoidal voltage at the generator DSG output, but the second channel provides the stepwise voltage at the generator GSV output. The maximal voltage on GSV output should not exceed the microcontroller supply voltage $V S$. Therefore, this voltage is practically equal to the countervailable range coverage. The voltage change step in the GSV output can be calculated as follows:

$$
\Delta V G S V=V S / n
$$

where $n$ is a number of DAC bits. In our case, if $V_{S}=3.3 / 4096=0.0008 \mathrm{~V}$, and $n=2^{12}=4096$, generator output voltage range is $V_{S}=3.3 \mathrm{~V}$. If the range coverage is $V_{R C}=20.4 \mathrm{~V}$ (absolute values range from $-10.2 \mathrm{~V}$ to $+10.2 \mathrm{~V}$ ), it is required to involve a separate amplifier at the generator GSV output having voltage gain factor $K_{V}$ (Fig. 1a), where $K_{V}=V_{R C} / V_{S}=20.4 / 3.3=6.2$, and $\Delta V_{B}=\Delta V_{G S V} \times K_{V}$.

Figure $1 \mathrm{~b}$ demonstrates two examples of bucking voltage $V_{B}(t)$ generated as described above by appropriate values of variable contact potential difference be- 
tween a conductive sample and a reference probe. From appearance of generated signal $V_{B}(t)$, it is possible to conclude that it consists of two stages (components). At the first, the main stage, the signal that is linearly increasing or decreasing reaches and hits the bucking voltage balance level (in example 1 it is $V_{B 1}=0=V_{C P D}$ ). The voltage polarity and value can differ at different head stage starting points (not shown in figures), and, for example, can depend on previous sample measurement. If $V_{C P D}$ value is not changing (it is constant) by the measurement time, in the both examples mentioned above the first stage is followed by the second stationary stage where the generated voltage is guided by variations of control signal at the generator GSV input, which leads to changes of voltage $V_{B}(\mathrm{t})$ initial direction and emergence of sawtooth oscillations around the average value of oscillation level with period $T_{B}=2 T$. This level characterises the level of bucking voltage at the balance moment $\left(V_{B 1}\right.$ and $-V_{B 2}$, respectively), which is equal and with opposite polarity to the value of respective potential $V_{C P D}$. The peak-to-peak amplitude of triangle voltage $V_{B p p}$ is chosen so that its value exceeds $\pm 20 \mathrm{mV}$ range several times. It is due to the above-mentioned precise measurement problems of an extremely weak Kelvin current at the area of balance point compensation where the signal-to-noise ratio reaches the minimum and the noise creates an offset voltage. Taking into account (1) and the amplification factor $K_{V}$, the peak-to-peak amplitude of triangle voltage is set by the expression

$$
V_{B p p}=\Delta V_{B} \cdot N
$$

where $N$ is a selected number of steps. In our case, if $\Delta V_{G S V}=0.8 \mathrm{mV}, K_{V}=6.2$ and $N=32, V_{B p p}=158.7 \mathrm{mV}$.

Accordingly, as a result of the above-mentioned and fixed [1], [6] interaction between the main linearly rising component of bucking voltage and its second - the triangular component, the variablie voltage with average value $V_{B}\left(V_{B 1}\right.$ or types $V_{B 2}$, see Fig. 1b) is generated. In its turn, the voltage $V_{B}$ corresponds to a compensatory value of measured voltage $\mathrm{CPD}$ at the balance point of these both voltages and alows fixing the value CPD.

It should be noted that the chosen triangular voltage peak-to-peak amplitude $V_{B P P}(2)$ is constant and maintains its value over the entire measuring range of contact potential diference.

The rate of speed $V_{B}(t)$ changes is characterised by ratio $\Delta V_{B} / \Delta t=V_{B p p} / 2 T$, which in our case is $\Delta V_{B} / \Delta t=158.7 \mathrm{mV} / 16.9364 \mathrm{~ms}=9.37 \mathrm{~V} / \mathrm{s}$.

The scanning of sample surface is practically carried out by many periodically repeated measurements. To shorten the total measurement time, the measurement is worked out based on shortening of the first stage of each individual measurement by increasing the speed of bucking voltage changes $\Delta V_{B} \Delta t$. This is developed by an algorithm that automatically increases $\Delta V_{B}$ values in accordance with the Kelvin current value at the beginning of measurement. The sample surface of the CPD measuring system is provided by the two-coordinate sample positioning mechanism controlled by two stepper motors in accordance with the control program. 
The mean distance $d_{0}$ between the sample electrode surface and the probe of experimental CPD measuring system is set manually proceeding from the image seen on the display. By the time of setting the installation regime for the measured sample, the plain gold layer coated over the sample standard glass plate is used, and the constant voltage is supplied to the probe gold electrode. At the output of measuring system, the voltage appears that is caused by Kelvin current, whose magnitude depends on the mean distance between electrode $d_{0}$. The voltage level for definite distance $d_{0}$ is set by more detailed manual regulation in accordance with image on the display. The distance $d_{0}$ setting procedure can be automatised [12]. The measured data (see Fig. 1a) are supplied from the analogue-to-discrete converter DAC output to the DISPLAY device, which includes the display of TFT LCD Panel SH128160T066-L03Q. The DAC input is connected to the generator GSV output. On the display, both values are shown, which are expressed in volts with resolution $1 \mathrm{mV}$ : the measured value $V_{C P D}$ and the difference between these $V_{C P D}$ readings and the gold probe surface potential (reference potential). Besides, there is the link "SET $\pm f$ " foreseen from the display device to the generator DSG for fine correction of sinusoidal frequency. The display operation is provided by the ATXMEGAI6A3U-AU type second microcontroller, which together with an optional regime switch is placed into the block of data acquisition system. At the output of display device, either the USB or the voltage-to-frequency converter with output "TO REG" can be provided for external data registration. The data acquired by the testing regime leads to a conclusion that if the output data integration time is $1 \mathrm{~s}$, the developed CPD measuring system for determination of the contact potential difference by Kelvin probe involving the composite bucking voltage provides the resolution of experimental measuring system in the range of $\pm(1-2 \mathrm{mV})$. This parameter can be improved using the 16-bit ADC instead of currently used 12-bit ADC inside the generator GSV.

The developed potential $V_{C P D}$ measuring device is provided with gold probe, whose surface potential is comparatively stabile and makes it possible to detect $V_{C P D}$ between the sample and the probe (as a reference). To carry out the actual work function measurements, a calibration is required because Kelvin probe needs to be calibrated in respect to the surface, whose work function is known. It is generally believed that under conditions of ambient air the gold has the work function around $4.9 \mathrm{eV}$. However, it is problematically to assess this value because the reaction of air components with the gold surface is possible. For example, if the gold films have been stored, it has been observed [13] that according to the storage time this value can reach a drift to $500 \mathrm{meV}$. The gaseous reaction studies of Kelvin probe [14] show a significant reaction of $\mathrm{NO}_{2}$ and $\mathrm{NH}_{3}$ with gold. There are examples [15], which show the use of gold film gaseous sensors, for example, for determination of gaseous $\mathrm{NO}_{2}$. This provides suggestions that for precise determination of absolute work function factor the preference should be given to the measurements in the vacuum. This problem can be solved to some extent if the inert materials are used. In this case, it is necessary to carry out two CPD measurements with Kelvin probe. The measurement with the measured sample $e\left(\Delta \Psi_{M P}\right)$ is taken first and afterwards with the reference material $e\left(\Delta \Psi_{I R}\right)$. Subsequently, the difference of both measurement results is calculated: 
$e V_{C P D}=e\left(\Delta \Psi_{M P}-\Delta \Psi_{I R}\right)=\left(\Phi_{M P}-\Phi_{A u}\right)-\left(\Phi_{I R}-\Phi_{A u}\right)=\left(\Phi_{M P}-\Phi_{I R}\right)$.

Thereby, the value $\Phi_{A u}$ is excluded from the calculation and variations of gold probe output work effects by time fall away. Under ambient conditions, the use of highly oriented pyrolytic graphite (HOPG) crystal is probably one of the best methods for calibration. Its work function about $4.6-4.7 \mathrm{eV}$ remains fairly stabile.

\section{CONCLUSION}

We feature a new and simple way enabling the determination of a contact potential diference (CPD) by entering the composite and time-varying bucking voltage in the Kelvin probe measuring circuit. The system is based on the generation of the electronically controllable CPD bucking voltage.

As a result of consecutive interaction of composite bucking voltage main component (raising or decreasing) and its triangular component, the variable voltage (with positive or negative polarity) is periodically generated. The averaging value of this voltage, in its turn, coresponds to a value of bucking voltage $V_{B}$ compensating the voltage $V_{C P D}$ measured in the CPD at the moment when the both voltages are balanced, wherewith it is possible to determine the value $V_{C P D}$. This way it is possible to avoid the row of measuring system disadvantages shown in [1], [6], which leads to the need of accurate determination of the value $V_{B}$ at the moment of achieving the balance between the two above-mentioned voltages when the current in the measured circuit is close to zero. In this case, precise measurement of current is complicated because the measured signal-to-noise ratio reaches minimum, and noise brings notable errors into the measurement.

The average value of composite bucking voltage generated by our measuring system is periodically and symultaneously detected and integrated, and its value with opposite polarity matches the measured contact potential difference $V_{C P D}$. Thus, the system continuously carrying on the "on-line" regime automatically keeps track on the measured value and noticeably avoids measuring inaccuracy related to the determination of super-weak current in the balance area of the both mentioned signals. The need of complex computer systems used traditionally to carry on the procedures of signal extrapolation for precisely setting down the voltages within the specified measuring range is eliminated. Components of the proposed measuring system are highly integrated, and the system is compact and of small size, which decreases the operating expenses of device and broadens the possibilities of its carrying into effect.

The measuring device is designed to determine CPD in the range of $+10.000 \mathrm{~V}$ up to $-10.000 \mathrm{~V}$ on the vibrating capacitor electrode surfaces representing the sample and the Kelvin probe electrodes. In our case, the chosen triangular voltage peak-topeak amplitude $V_{B P P}$ is constant and maintains its value over the entire CPD measuring range.

System adjustment can be performed easily and fast. Experimental measurement system test results have shown stable measurement resolution in the range of $\pm(1-2 \mathrm{mV})$. 
The data acquisition system of our measurement device is supplied with a display, which allows for an easy setting of the performance measuring regime and visually keeping track of the measurement procedure.

\section{REFERENCES}

1. Vilitis, O., Rutkis, M., Busenbergs, J., and Merkulovs, D. (2016). Determination of contact potential difference by the Kelvin probe (Part I). 1. Basic principles of measurements probe. Latv. J. Phys. Techn. Sci., 2, 48-57.

2. Palevsky, H., Swank, R.K., and Grenchik, R. (1947). Design of dynamic condenser electrometers. Rev. Sci. Instrum, 18, 298-314.

3. Mitchinson, J.C., Prongle, R.D., and Farvis, W.E.J. (1971). Surface potential measurement using a rotating dynamic capacitor. J.phys., E 4, 525-529.

4. Petit-Cloerc, Y., and Carette, J.D. (1968). New feedback Kelvin probe. Rev. Sci. Instrum., 38, 933-934.

5. Blott, B.H., and Lee, T.J. (1969). A two frequency vibrating capacitor method for contact potential diference measurements. $J$. Phys., 2, 785-788.

6. Maljusch, A. (2012). Integrated scanning Kelvin probe - Scanning electrochemical microscopy system: Design, development and applications. Diss. 1-245.

7. Ritty, B., Wahtel, Ott, F., Manquenouille, R., and Donnet, J.B. (1980). New application of the Kelvin method involving the scanning of the bucking voltage. Rev. Sci. Instrum., 51 (10), 1421-1423.

8. Baikie, I.D., van der Werf, K.O., Broeze, J., and van Silfhout, A. (1989). Automatic Kelvin probe compatible with ultrahigh vacuum. Rec. Sci. Instrum. 60, 930.

9. KP Technology. USA Inc. Available at www. kelvinprobe.com

10. Vilitis, O., Fonavs, E., and Muzikante, I. (2001). A system for measuring surface potential by the Kelvin-Zisman vibrating capacitor probe. Latv. J. Phys. Techn. Sci., 5, 38-56.

11. Rossi, F. (1992). Contact potential measurement: The preamplifier. Rev Sci. Instr., 63 (7), 3744-3751.

12. Neufeld, A.K., Bond, A.M., and Cole, I.S. (2003). Construction and operation of a Kelvin probe instrument. Chapter 3, 29-88.

13. Hansen, W.N., and Johnson, K.B. (1994). Work function measurements in gas ambient. Surface Science, 316, 373-382.

14. Toda, K., Ochi, K., and Sanemasa, I. (1996). Non-sensing properties of Au thin film. Sensors and Actuators, B 32, 15-18.

15. Ostrick, B. (2000). Die Untersuchung der Karbonat - Kohlendioxid - Wechselwirkung im Feuchtefilm der Oberfläche. Diss. 1 - 131. 


\title{
KONTAKTPOTENCIĀLU STARPĪBAS \\ NOTEIKŠANA AR KELVINA ZONDI
}

\author{
(II DAL,A) \\ 2. MĒRİ̌̌SANAS SISTĒMA, IESAISTOT \\ KOMPOZĪTU PRETSPRIEGUMU
}

\author{
O. Vilīis, M. Rutkis, J. Busenbergs, D. Merkulovs
}

Kopsavi $1 \mathrm{kums}$

Rakstā esam parādījuši iespējas izveidot augstas precizitātes, kompaktu, lētai un ērtai lietošanai kontakta potenciālu starpības mērīšanas veidu ar Kelvina zondi, kas ḷauj regulāri noteikt kontakta potenciālu diferences (CPD) spriegumu $V_{C P D}$, ievadot šīs zondes mērǐšanas k̦ēdē kompozītu un laikā periodiski mainīgu kompensējošu pretspriegumu. Kompozītā pretsprieguma galvenās - augoša vai krītoša sprieguma komponentes un otras - trīsstūrveida sprieguma komponentes secīgas mijiedarbības rezultātā, tiek periodiski ǵenerēts pozitîvas vai negatīvas polaritātes mainīgs spriegums. Šì sprieguma vidējotā vērtība savukārt atbilst pretsprieguma $V_{B}$ lielumam, kas kompensē mērāmā CPD spriegumu $V_{C P D}$ abu šo spriegumu balansa brīdī un, līdz ar to, l̦auj noteikt $V_{C P D}$ vērtību. Ar to tiek sniegta iespēja izvairīties no virknes mērīšanas sistēmu trūkumiem, norādītiem [1], [6], ko izraisa nepieciešamība precīzi fiksēt $V_{B}$ vērtību tieši minēto spriegumu balansa brīdī, kad strāva mērīšanas ķēēē pietuvināta nullei un tās precīzu mērīšanu sarežǵī mērāmā strāvas signāla un trokšña attiecības, kas mērāmās strāvas apgabalā sasniedz minimumu un trokšņi ienes ievērojamas kḷūdas mērījumā.

Mūsu mērīšanas sistēmā ǵenerētā kompozītā pretsprieguma vidējā vērtība tiek periodiski digitālā veidā sinhroni detektēta un integrēta, un tās pretējās polaritātes lielums atbilst mērāmajam CPD spriegumam $V_{C P D}$. Līdz ar to sistēma nepārtraukti 'on-line' režīmā automātiski seko mērāmajam lielumam un ievērojamā mērā apiet mērī̌sanas neprecizitātes, saistītas ar l̦oti vājas strāvas noteikšanu abu minēto signālu balansa apgabalā. Tādējādi atkrīt sarežǵìtu datorsistēmu nepieciešamība, kas tradicionāli tiek pielietotas, lai veiktu signālu ekstrapolešanas procedūras, precīzi nosakot sprieguma vērtības norādītajā mērīšanas apgabalā. Piedāvātās mērīšanas sistēmas komponentes ir augsti integrētas, un tā ir izveidota kompakta un izmēros maza, kas, kopā ņemot, samazina mērierīces ražošanas izmaksas un paplašina tās pielietošanas iespējas.

Izveidotās eksperimentālās sistēmas pārbaudes rezultāti CPD mērīšanas robežās no $+10.000 \mathrm{~V}$ līdz $-10.000 \mathrm{~V}$ ir pierādījuši stabilu $\pm(1-2 \mathrm{mV})$ mērīšanas izšķirtspēju. Mūsu gadījumā izvēlētā kompozītā pretsprieguma trīsstūrveida sprieguma komponentes pilna maksimumu amplitūda $V_{B p p}$ ir pastāvīga un saglabā savu vērtību visā CPD sprieguma $V_{C P D}$ mērīšanas diapazonā.

Mērīšanas sistēma ir apgādāta ar displeju, kas ḷauj êrti uzstādīt mērījumu izpildes režīmu un vizuāli sekot mērīšanas gaitai.

30.09.2016. 